\title{
Clinical Symptoms of Patient with Heart Failure in Dr. Soetomo General Hospital: A Descriptive Study
}

\author{
Niki Kusuma Bangsa1 ${ }^{1}$, Rochmad Romdoni ${ }^{2} \mathbb{D}$, Subagyo $^{3}$
}

${ }^{1}$ Faculty of Medicine, Universitas Airlangga, Surabaya, Indonesia.

${ }^{2}$ Department of Cardiology and Vascular Medicine, Faculty of Medicine, Universitas Airlangga/Dr. Soetomo General Hospital, Surabaya, Indonesia.

${ }^{3}$ Department of Physical Medicine \& Rehabilitation, Universitas Airlangga/Dr. Soetomo General Hospital, Surabaya, Indonesia.

\section{A B S T R A C T}

Introduction: Heart failure (HF) has emerged as a cardiovascular disease with high prevalence in developing countries. The highest number was expected to increase over the next few decades. Moreover, most people with HF do not show specific symptoms earlier, thus death often occurs. This study was undertaken to give an insight into the clinical symptoms and risk factors of HF.

Methods: This cross-sectional study utilized medical records from Dr. Soetomo General Hospital between 6 months (July-December 2016). Eligibility criteria included female patients diagnosed with HF at the hospital with a classification of NYHA I-IV. Risk factors data from the participants such as hypertension, diabetes mellitus, dyslipidemia, body mass index (BMI), smoking status, and history of cardiovascular disease were collected. Clinical symptoms were reported descriptively.

Results: From 84 patients admitted with HF in the hospital from July until December 2016, 53 were males (63.1\%). In all groups, hypertension (35.6\%) was the highest prevalence risk factor, followed by diabetes mellitus $(25.3 \%)$, and a history of cardiovascular disease (17.2\%). In this study, the most common symptom was shortness of breathing, contributing to $72.6 \%$, followed by chest pain $(10.7 \%)$, and body weakness $(6 \%)$.

Conclusion: This study concluded that most of the respondents were male, aged 46-65 years old. The highest risk factor that contribute to an HF was hypertension. The most common symptom in patients with HF in the hospital was shortness of breathing. Studies further emphasize the need for primordial prevention related to symptoms and risk factors of HF.

\section{*Correspondence: r.romdoni@yahoo.com}

JUXTA: Jurnal IImiah Mahasiswa Kedokteran Universitas Airlangga

p-ISSN: 1907-3623; e-ISSN: 2684-9453

DOI: $10.20473 /$ juxta.V12I22021.57-60

Open access under Creative Commons Attribution-ShareAlike 4.0 International License (CC-BY-SA)

\section{ARTICLE INFO}

Article history:

Received 3 March 2021

Received in revised form 9 July 2021

Accepted 2 August 2021

Available online 31 August 2021

\section{Keywords:}

Cardiovascular disease,

Heart failure,

Human \& disease,

Human \& health,

Human \& illness. 


\section{Introduction}

Heart failure (HF) is a cardiovascular disease that has a high prevalence. According to statistical data, there are more than 23 million cases of HF worldwide. Meanwhile, in developing countries, the incidence has continued to increase from 1.5-4\% to 6.7-9\%. ${ }^{1,2}$ Based on the data from Basic Health Research, the number of people with HF in Indonesia in 2013 was $0.13 \%$, or around 229,696 people, and that number will continue to increase with the increasing age of sufferers because HF is more at risk in the elderly population (aged $50-60$ years old). ${ }^{3-5}$ Most people with HF are estimated to be in East Java, namely 54,826 people $(0.19 \%)$, and are predicted to continue to increase in the coming decades. ${ }^{4}$

$\mathrm{HF}$ is the last and worst manifestation in almost all types of heart disease, such as coronary heart disease, heart valve disease, hypertension, congenital heart disease, cardiomyopathy, and all conditions that can cause changes in the structure and function of the heart. ${ }^{6,7}$ Therefore, all of these are predisposing factors that can develop into HF at a later date.

If viewed from the disease course, HF can be with or without an initial acute attack or without a history of previous heart disease. ${ }^{5}$ Most people who experience HF do not have specific symptoms in the early phase to affect the patient's perception of acute symptoms. ${ }^{6,8}$ Less typical signs and diagnostic uncertainty are likely to contribute to delayed treatment contributing to the increased mortality in HF patients. This study aims to determine the clinical characteristics and risk factors for HF patients treated at Dr. Soetomo General Hospital from July to December 2016.

\section{Methods}

This was a cross-sectional study that utilized medical records. The study population was all HF patients treated at Dr. Soetomo General Hospital from July to December 2016. The population in this study amounted to 178 respondents, while the sample that met the inclusion criteria was 84 respondents. The inclusion criteria in this study were patients with a diagnosis of HF with or without other comorbidities accompanied by New York Heart Association (NYHA) I-IV criteria. While the exclusion criteria included patients who were not proven to have a diagnosis of HF either clinical, laboratory, electrocardiography, echocardiography, or chest X-ray (CXR); patients with incomplete medical records or do not have any of the following components: patient identity, baseline data, risk factor data such as hypertension, diabetes mellitus, dyslipidemia, body mass index (BMI), smoking status, history of cardiovascular disease.

The research variables included age, gender, primary complaint, and patient risk factors. The age category in this study refers to the Indonesian Ministry of Health, which divides into six age categories, namely toddlers (0-5), children (6-11), adolescents (12-25), adults (26-45), elderly
(46 -65), and seniors (> 65). ${ }^{3}$ The main complaints and risk factors were assessed at the time the patient entered the ER. Hypertension criteria according to $\mathrm{WHO}$ if systolic pressure $>140 \mathrm{mmHg}$ and/or diastolic $>90 \mathrm{mmHg}^{9}$

\section{Results}

Data on demographic characteristics and clinical complaints of patients can be seen in Table 1 and Table 2 . Meanwhile, Table 3 describes the distribution of risk factors for patients with HF (a patient may have $>1$ risk factor).

Table 1. Distribution of characteristic of the respondents based on demographic data $(n=84)$

\begin{tabular}{clcc}
\hline No & Characteristics & Frequency (n) & Percentage (\%) \\
\hline 1. & Gender & & \\
& Male & 53 & 63.1 \\
& Female & 31 & 36.9 \\
2. & Age (year) & & \\
& $0-5$ & - & - \\
$6-11$ & - & - \\
$12-25$ & 4 & 4.8 \\
$26-45$ & 19 & 22.6 \\
$46-65$ & 49 & 58.3 \\
& $>65$ & 12 & 14.3 \\
\hline
\end{tabular}

Table 1 shows that the highest age frequency among 84 respondents is in the elderly (46-65 years old), about 49 respondents (58.3\%). Regarding gender, 53 respondents were dominated by males $(63.1 \%)$. Furthermore, the distribution of the main symptoms in ER are described in Table 2 below.

Table 2. Distribution of symptoms in respondents $(n=84)$

\begin{tabular}{clcc}
\hline No & Symptoms & Frequency $(\mathbf{n})$ & Percentage (\%) \\
\hline 1. & Edema & 1 & 1.2 \\
2. & Weakness & 5 & 6 \\
3. & Shortness of & 61 & 72,6 \\
breathing & Chest pain & 9 & 10.7 \\
5. & Heartburn & 2 & 2.4 \\
6. & Abdominal pain & 2 & 2.4 \\
7. & Leg pain & 2 & 2.4 \\
8. & Unconsciousness & 2 & 2.4 \\
\hline
\end{tabular}

Based on Table 2, most subjects have shortness of breathing as the common symptom contributing to $72.6 \%$, followed by chest pain (10.7\%) and body weakness (6\%).

\begin{tabular}{|c|c|c|c|}
\hline No & Risk factor & Frequency $(\mathrm{n})$ & Percentage (\%) \\
\hline 1. & $\begin{array}{l}\text { Diabetes } \\
\text { mellitus }\end{array}$ & 22 & 25,3 \\
\hline 2. & Dyslipidemia & 6 & 6,9 \\
\hline 3. & Hypertension & 31 & 35,6 \\
\hline 4. & Smoking & 11 & 12,6 \\
\hline 5. & Obesity & 2 & 2,3 \\
\hline 6. & $\begin{array}{l}\text { Coronary heart } \\
\text { disease }\end{array}$ & 15 & 17,2 \\
\hline
\end{tabular}

Table 3 shows that hypertension as the highest prevalence of risk factor in $\mathrm{HF}$, there was about 31 respondent $(35.6 \%)$, then followed by diabetes mellitus $(25.3 \%)$ and history of cardiovascular disease (17.2\%). 


\section{Discussion}

\section{Subject Demographic Characteristics}

This study indicates that the majority of HF patients in the sample group are male and elderly aged 46-65 years old. The results in table 1 are by the research of Kristoforus, et al. (2015), ${ }^{6}$ Tambuwun, et al. (2016), ${ }^{10}$ and Purnamawati, et al. $(2018)^{11}$ which explains that the prevalence of HF is mostly found in males. These results are also following Gultom's research (2017) which explains if the male gender $(77 \%)$ in the $56-65$ year age group dominates congestive HF patients at $\mathrm{H}$. Adam Malik General Hospital Medan. ${ }^{12}$ This is often associated with a risk factor for smoking, which is more common in men than women10. The results of this study are also from the research of Yayang, et al. (2016) ${ }^{8}$ which explains that the highest prevalence of HF patients aged 45-65 years old in Cardiology Clinic of PKU Muhammadiyah Gamping Sleman Hospital is 61-65 years old. A study conducted by Basic Health Research revealed that people with HF are in the age group $>45$ years old and have increased according to age because theoretically, the function of body organs will decrease with age, including heart and blood vessel function as the cause of HF. ${ }^{3,9}$ According to Karavidas, et al. (2010), ${ }^{13}$ increasing age is identical to the progressive dysfunction of body organs and affects maintaining homeostasis. Therefore, elderly patients are more at risk of atherosclerosis as a predictor of HF later in life..$^{9,13}$

\section{Subject Clinical Characteristics}

In the distribution based on the patient's main complaint, the most complaints were shortness of breathing. This is following the study of Goldberg, et al. (2010) which explains that $93 \%$ of HF patients have symptoms of shortness of breath. ${ }^{14}$ In the study of Adhikari, et al. (2013), who conducted a retrospective study of elderly patients with HF due to mitral valve stenosis, it was found that all these patients had complaints of shortness of breath as the main symptom. ${ }^{15}$ The results of this study are also supported by research by Barnett, et al. (2017), which explains that in the population of cardiovascular disease (ischemic heart disease and HF) patients that have been studied, common symptoms in patients are shortness of breathing and chest pain with or without trigger factors. ${ }^{16}$ Symptoms of shortness of breath are most likely correlated with the failure of the left ventricle to pump oxygen-rich blood throughout the body resulting in symptoms of decreased cardiac output (CO) such as shortness of breath on exertion or shortness of breath at rest. ${ }^{17}$ These data provide clues that there are differences in the main complaints in this study due to different etiologies that underlie HF. ${ }^{18}$

The most significant risk factor in this study was hypertension. The prevalence of hypertension in HF patients in Dr. Soetomo General Hospital (35.6\%) was not significantly different from the prevalence found in previous studies, either by Kristoforus, et al. (57.1\%), ${ }^{5}$ Rudolof, et al.
$(37 \%),{ }^{7}$ or Gultom (26.4\%). ${ }^{12}$ Previous studies have explained that hypertension is the most common risk factor, namely $70 \%-80 \%$ for HF patients, because hypertension can cause severe damage to the heart. ${ }^{10}$ The second risk factor is diabetes mellitus (25.3\%). Indonesia, Pakistan, and Bangladesh are among the top ten people with diabetes. Asian populations are thought to have a higher risk of diabetes due to a greater tendency to suffer from abdominal obesity. ${ }^{5}$ These factors support the trend of increasing the prevalence of cardiovascular disease sufferers in Indonesia. These results follow the research conducted by Nugraha (2017), which explains the most comorbidities in HF cases at Dr. Wahidin Sudirohusodo Makassar: hypertension and diabetes mellitus. ${ }^{19}$ The number of HF patients with hypertension (29\%) while the number of patients with diabetes mellitus was $26.9 \%$. This is by the literature, which shows that hypertension and diabetes mellitus are the highest factors for HF, especially in Southeast Asia.

\section{Conclusion}

This study identified the characteristics of age, gender, main complaints, and risk factors for HF. Most of the respondents were male, aged 46-65 years old, who came with complaints of shortness of breath and had risk factors for hypertension.

The results of this study are expected to be a reference for knowing the characteristics of patients with HF, especially clinical symptoms and risk factors, so that prevention or intervention can be done to reduce the recurrence of HF patients. Researchers can then research by providing intervention for HF patients with a larger sample size.

\section{Acknowledgments}

The authors would like to thank the medical record officer of Dr. Soetomo General Hospital, Surabaya who helped in this study.

\section{CONFLICT OF INTEREST}

The author stated there is no conflict of interest in this study.

\section{REFERENCES}

1. Roger VL. Epidemiology of Heart Failure. Circ Res 2013; 113: 646-659.

2. Siswanto B, Radi B, Kalim H, et al. Heart Failure in NCVC Jakarta and 5 hospitals in Indonesia. CVD Prev Control 2010; 5: 35-38.

3. Indonesia KKR. Situasi Kesehatan Jantung. Hari Jantung Sedunia, 2014, pp. 1-8.

4. Indonesia KKR. Riset Kesehatan Dasar 2013. Jakarta, 2013.

5. Djaya KH, Nasution SA, Antono D. Gambaran Lama Rawat dan Profil Pasien Gagal Jantung di Rumah Sakit Cipto Mangunkusumo. Indones J CHEST Crit Emerg Med 2015; 2: 141-150. 
6. Clark AP, McDougall GJJ, Joiner-Rogers G, et al. Explanatory Models of Heart Failure Etiology. Dimens Crit Care Nurs 2012; 31: 46-52.

7. Donsu R, Rampengan S, Polii N. Karakteristik Pasien Gagal Jantung Akut di RSUP Prof Dr. R. D. Kandou Periode Januari-Desember 2018. Med Scope J; 1. Epub ahead of print 15 January 2020. DOI: 10.35790/msj.1.2.2020.27463.

8. Harigustian $Y$, Dewi A, Khoiriyati A. Gambaran Karakteristik Pasien Gagal Jantung Usia 45 - 65 Tahun di Rumah Sakit PKU Muhammadiyah Gamping Sleman. Indones J Nurs Pract; 1. Epub ahead of print 1 December 2016. DOI: 10.18196/ijnp.1152.

9. Indonesia PDSK. Pedoman Tatalaksana Penyakit Gagal Jantung. Jakarta, 2015.

10. Tambuwun C, Panda A, Rampengan S. Gambaran Pasien Gagal Jantung dengan Penyakit Hipertensi yang Menjalani Rawat Inap di RSUP Prof. Dr. R. D. Kandou Manado Periode September - November 2016. e-CliniC; 4. Epub ahead of print 12 July 2016. DOI: $10.35790 /$ ecl.4.2.2016.14680.

11. Purnamawati DA, Arofiati F, Relawati A. Gambaran Karakteristik Pasien Gagal Jantung dengan Supportive-Educative System. In: Prosiding Konferensi Nasional Ke-7. Yogyakarta: Asosiasi Program Pascasarjana Perguruan Tinggi Muhammadiyah 'Aisyiyah (APPPTMA), 2018, pp. 47-52.
12. Gultom DTJ. Profil Pasien Gagal Jantung Kongestif di RSUP Haji Adam Malik Medan Periode Juli hingga Desember Tahun 2016. Universitas Sumatera Utara, 2017.

13. Karavidas A, Lazaros G, Tsiachris D, et al. Aging and the Cardiovascular System. Hell J cCrdiology HJC $=$ Hell Kardiol Ep 2010; 51: 421-427.

14. Goldberg RJ, Spencer FA, Szklo-Coxe M, et al. Symptom Presentation in Patients Hospitalized with Acute Heart Failure. Clin Cardiol 2010; 33: E73-80.

15. Adhikari $\mathrm{CM}$, Malla $\mathrm{R}$, Rajbhandari $\mathrm{R}$, et al. Percutaneous Transvenous Mitral Commissurotomy in Elderly Mitral Stenosis Patients. A Retrospective Study at Shahid Gangalal National Heart Centre, Bansbari, Kathmandu, Nepal. Maedica (Buchar) 2013; 8: 333-337.

16. Barnett LA, Prior JA, Kadam UT, et al. Chest Pain and Shortness of Breath in Cardiovascular Disease: A Prospective Cohort Study in UK Primary Care. BMJ Open 2017; 7: e015857.

17. Mariyono HH, Santoso A. Gagal Jantung. J Intern Med 2008; 9: 85-93.

18. Chapman B, DeVore AD, Mentz RJ, et al. Clinical Profiles in Acute Heart Failure: An Urgent Need for a New Approach. ESC Hear Fail 2019; 6: 464-474.

19. Nugraha IS. Karakteristik Pasien Gagal Jantung Rawat Inap di RSUP Dr. Wahidin Sudirohusodo Makassar Periode 1 Januari - 30 September 2017. Universitas Hasanuddin, 2017. 